\title{
Getting to Ten
}

\author{
Ben Agger, Timothy W. Luke
}

Nearly a decade ago on the eve of the Great Recession, we believed that new publishing possibilities afforded to anyone with sufficient Internet connectivity and enough intellectual contacts provided an outlet for the historical sociology, cultural studies, political economy, and aesthetic criticism that anchors critical social theory. Older existing print journals had not yet fully made their ways into the digital domain, and maybe some of them never would. What could a "born digital" journal do differently, how might it create new scholarly networks, who would join its experiments from across the academy, around the world, and alongside the established media ecologies of print journals? Running with this sense of curiosity, and pushing ahead with a willingness to give it a try, Fast Capitalism journal posted its 1.1 issue in 2005.

Our journal was born of excitement about interdisciplinary critical theory and cultural studies, and frustration about existing so-called peer reviewed journals. There are two types of faculty-those with strong and singular disciplinary identities (e.g., chemist, economist, psychologist) and others of us with diffuse and multiple identities, such as cultural studies and critical theory. We are at home nowhere and everywhere, and this is an outlet for people like us! Our editorial board reflects the fact that most of us are of the second type, working across, and between, disciplines. Fast Capitalism not only bridges disciplines; it connects social and cultural studies. As well, we were frustrated by traditional so-called refereed journals that use peer reviewing as a political shield. We are convinced that editing is undecidable authorial work, which is to say that editors have a great deal of control over what they publishpicking reviewers, reading and interpreting reviews, passing advice back to authors, making final editorial decisions. The process is far from objectively grounded in a Platonic notion of quality or merit. It is, as all readings are, political. We resist and deplore the editorial will to power, which pretends that there is an Archimedean standard of quality that is external to the busy, muddy literary work that underlies intellectual life. As Derrida said, there is nothing outside the text, by which he meant that it is impossible to escape the prison house of language, first identified by Nietzsche. Paraphrasing Merleau-Ponty, where he acknowledges the difficulty of predicting the timing of a socialist revolution, editorial standards are not written indelibly on any wall nor inscribed in a metaphysical heaven. We are Nietzchean Frankfurters open to French insights about texts, writing and reading, and it is clear that what we publish here reflects our frustration with (call it) positivist editing.

Whether authors who publish in our pages can reap career capital is somewhat beside the point. Certain U.S. disciplines, such as English, more quickly validated electronic publication than have some of the social science disciplines. Inasmuch as it is nearly impossible to remain invisible on the Internet, we suspect that our articles have impact, even as they may fall through the cracks of disciplinary valorization for hiring, tenuring and promoting purposes. Perhaps in ten years, most of us will be driving down the road in hybrids, and, similarly, books and articles will be issued mainly, or only, in electronic form. The crisis of book publishing certainly suggests this possibility.

Moving the journal from an idea into actual implementation amid what was then uncertain acceptance of purely digital content, we believed Fast Capitalism would be a test for the wide-open possibilities of "open source" scholarly publishing. The contradictions created by greater connectivity and multiple scholarly communities becoming trapped in the intellectual property rights regime of print capitalism were, and still are, quite real. The chance to get new ideas to more people even faster, while maintaining a sense of a free intellectual commons, had been possible for nearly a decade. Yet, too few were truly trying something new. Clearly, Fast Capitalism's authors and audiences have been frustrated by the overly compartmentalized and strangely disciplinary leanings of far too many established 
print outlets as they puzzled their paths through these evolving publication possibilities. No longer needing to watch and wait, we launched Fast Capitalism as an exploration in open source, multi-media, mixed method, and cross-disciplinary discourse to speak from the Left to any who would listen. Taking "fast capitalism" as its title from Agger's 1989 book with the University of Illinois Press, the journal has endeavored in many respects to be a critique of the political economy and sociology that Luke's 1989 book, also with the University of Illinois, mapped out as "screens of power." It is fitting that our journal is available on the screen.

As we anticipated in Year Zero of the post-Cold War terrains of the "New World Order," the organic connections between accelerating, expanding, and intensifying fast-capitalist exchange and the seductive, secretive, and selective screening of power have only become more fascinating and significant over the past quarter century as many new nations and economies have become ensnared in their own constant contact with $24 \mathrm{x} 7$ transnational exchange in the development of actually existing neoliberalism. While some academic journals and a few engaged sites of critical discourse did address their import, none did so with the eclectic scope and effective focus we believed was necessary. After the dismal re-election of George W. Bush in 2004, the reckless choice by the U.S. and its "coalition of the willing" to go to war in Iraq in 2003, the loss of that coalition's sense of mission for the Afghan intervention in 2002, the shocking Al Queda terrorist attacks in 2001, and the miserable institutional failures experienced during 2000 by the "world's sole remaining superpower" in the Bush/Gore presidential contest as well as the popping of the dotcom economic bubble, 2005 definitely seemed like an opportune moment to wade into the flow of discourse rising on the Internet in e-journals, web logs, e-books, and listservs. It was time to consider the uncommon crises that the U.S. and the world at large have been confronting in the 21 st century.

With little institutional support beyond a bare minimum bandwidth provision, software application support, benign silent tolerance, and occasional news releases from our home campuses at the University of Texas-Arlington and Virginia Polytechnic Institute \& State University, Fast Capitalism launched issue 1.1 during mid-2005 after several months of preliminary development and extended discussion. Using standard simple HTML constructs, deploying a few flash pages juxtaposing images of contemporary capitalism, the journal used images, sound, music, and movement to introduce old and new generations of authors to new audiences in the Anglophone infosphere. Matthew Levy designed the journal, keeping its look spare and to the point. Noah Kersey has assumed the managing editorship, and does the arduous coding work that makes publication possible. He is our means of production.

Some Fast Capitalism writers have been at their trade since the 1960s, while others published their first articles as intellectuals in Fast Capitalism in the 2000s. Even though it is posted in the U.S., the journal is a global publication that has invited contributions from around the world as well as taken up topics of concern in every corner of the world. The writing is political and critical, but it also can be introspective and reflective as authors think through questions of theory and practice, rationality and emotion, order and disorder, personality and society.

Like many journals, it expresses the personal interests, professional networks, and political engagements of the editors, its advisory board, and the authors who publish in it. Yet, it also has captured, if only in part, many currents in mainstreams of our 21st century Zeitgeist, rising from many events that have marked the contours the past decade. Like 10.1, 1.1 was anchored by a major multimedia work organized by Robert Goldman, and this initial number investigated the technocultures of speed, power, and capital. 2.1 in 2006 continued this interest with another collection of contributions on technocapitalism and its destructively creative practices. In early 2007, 2.2 examined animal rights, the critical theory of nature developed by William Leiss, and other questions of environmental order/ disorder. The concerns of textuality and new media preoccupied 4.1 in 2008, while 5.2 in 2009 looked into the dynamics of social media like Facebook. 6.1 in 2009 was a special examination of narrative, biography, and identity with elaborate online art presentations and works of reflective writing. The global economic crisis was at the center of 7.1 in 2010, and 8.1 in 2011 was another special issue tied to studies of Slovenia, the European project, and crisisridden capitalism. The disruptive role of new media in the academy concerned many of the pieces in 8.2 during 2011 , while the implications of the global "Occupy Wall Street" movements tied together many of the studies presented in 9.1 during 2012.

Along the way, two other issues - 3.1 in 2007 that focused on the April 16, 2007 shootings at Virginia Tech and 5.1 in 2009 that reflected back on the influence of Paul Piccone and his journal Telosin "the Americanization of critical theory" since the 1960s - were quickly picked up by established publishing houses to appear as bound print books respectively in 2008 and 2011. The Virginia Tech book was issued by Rowman \& Littlefield, and the book on Piccone's legacy appropriately appeared under the imprint of Telos Press. Likewise, issue 10.1 initially was planned around the theme of "gun violence and public life" in the wake of the 2012 shootings at Sandy Hook Elementary 
School in Newton, Connecticut, but this compendium of papers went instead directly into production as a bound book with Paradigm Publishers.

What comes next is always difficult to foretell, but there will be a Fast Capitalism 10.2 and/or 11.1. To get there, and beyond, we invite you to join the debates that have unfolded here for nearly a decade. 
